\title{
PENGARUH PERTUMBUHAN EKONOMI, PAD, DAU DAN DBH TERHADAP BELANJA DAERAH PROVINSI ACEH 2013-2017
}

\author{
Yois Nelsari Malau ${ }^{1}$ \\ Weni Listayani Lase ${ }^{2}$ \\ Vera Clodia Br Sagala ${ }^{3}$ \\ Dedek Lestari ${ }^{4}$
}

\begin{abstract}
Fakultas Ekonomi Universitas Prima Indonesia, Sumatera Utara, Indonesia ${ }^{1,2,3,4}$ Email:wenilista@gmail.com ${ }^{2}$
\end{abstract}

\begin{abstract}
The study aims to examine the effect of economic growth, local revenue, general allocation fund, and revenue sharing fund on regional expenditure in Aceh province of 2013-2017. Population and sample amounted to 23 districts/cities from 2013-2017, using saturated sampling techniques. Gained the coefficient of determination analysis was 0.864 , meaning that the variable in regional expenditure were able to explain by variable economic growth, regional indigenous revenue, general allocation fund, and revenue share fund up to $86.4 \%$ and other free variables of 13,6\%. The results of partial that economic growth, local revenue, and general allocation fund affect and significance, while revenue sharing fund is no affect on the regional expenditure. And simultaneously economic growth, local revenue, general allocation fund, and revenue sharing have an impact on the regional expenditure.
\end{abstract}

Keywords : Economic Growth; Local Revenue; General Allocation Fund; Revenue Sharing Fund; Regional Expenditure

\begin{abstract}
ABSTRAK
Penelitian ini bertujuan mengkaji bagaimana pengaruh antara PDRB, PAD, DAU, dan DBH pada belanja daerah di Provinsi Aceh periode 2013-2017. Populasi dan sampel berjumlah 23 kabupaten/kota dari tahun 2013-2017, dengan menggunakan teknik sampling jenuh. Diperoleh Koefisien Determinasi sebesar 0,867, artinya variabel belanja daerah yang mampu dijelaskan oleh variabel PDRB, PAD, DAU, dan DBH pada belanja daerah sebesar $86,7 \%$, dan variabel bebas lain sebesar $13,3 \%$. Hasil pembahasan menyatakan secara parsial PDRB, PAD, dan DAU memiliki pengaruh dan signifikan sedangkan DBH tidak ada pengaruh terhadap belanja daerah. Dan secara simultan PDRB, PAD, DAU, dan DBH memiliki pengaruh terhadap belanja daerah.
\end{abstract}

Kata Kunci : Pertumbuhan Ekonomi; Pendapatan Asli Daerah; Dana Alokasi Umum; Dana Bagi Hasil; Belanja Daerah 


\section{PENDAHULUAN}

Penetapan Undang-undang Nomor 32 tahun 2004 mengenai Pemerintahan Daerah menjadikan struktur pemerintahan menjadi lebih bersifat desentralisasi. Dimana, pemerintahan pusat menyerahkan kebebasan pada pemerintahan daerah menata rumah tangganya sendiri terutama mengembangkan potensi pemerintahannya. Pemerintahan daerah diberi otoritas dalam penggunaan finansialnya berdasarkan harapan serta keperluan masing-masing daerah tanpa banyak campur tangan pemerintahan pusat.

Otonomi daerah diharapkan mampu berdampak positif meningkatkan pertumbuhan ekonomi sebagai preferensi utama tiap daerah (Sukirno 2016). Khusus untuk pertumbuhan daerah biasa dihitung menggunakan PDRB atas dasar harga konstan. Pertumbuhan ekonomi memang bukan sasaran tunggal di Negara berkembang, tetapi menjadi syarat utama dalam memperbaiki kesejahteraan masyarakat serta kepentingan pembangunan lainnya.

Pemberian desentralisasi fiskal membebaskan pemerintahan daerah mengelola seluruh sumber pendapatannya berupa PAD dalam membiayai pengeluaran dalam rangka pertumbuhan dan pembangunan ekonomi daerah. Dengan PAD yang dimiliki, maka kebutuhan-kebutuhan daerah tersebut pun dapat terpenuhi. Meskipun, banyak daerah yang masih berharap kepada sumber pendanaan yang lain dan tidak mengelola PAD yang ada.

Di samping PAD, dana transferan dari pemerintahan pusat menjadi sumber pendanaan pemerintah daerah. Dalam penelitian ini, dana transferan tersebut berupa 
DAU dan DBH. Keduanya memberi peran yang saling berhubungan bagi pemerintah daerah. Dana trasferan yang cukup tentu menjadi sumber pendanaan yang sangat berpotensi meningkatkan kesejahteraan masyarakat. Dana tersebut juga diharapkan dapat menjadi penghubung antar daerah terutama dengan pusat.

Dalam APBD, daerah menggunakan penghasilan yang diterima untuk membiayai belanja daerah. Pengalokasian dana belanja daerah menjadi standar keberhasilan terlaksananya kewenangan daerah. Semua pengeluaran tersebut diharapkan berfokus pada urusan pemerintah dan pemenuhan kebutuhan masyarakat saja meskipun kenyataannya masih banyak ditemukan ketimpanganketimpangan dan ketergantungan yang besar oleh pemerintah daerah terhadap pemerintahan pusat.

Seperti kasus pada penelitian ini, yakni pada kabupaten Aceh Singkil dan Aceh Utara. PDRB dan PAD di kabupaten Aceh Singkil mengalami peningkatan pada tahun 2016-2017 masing-masing sebesar 61.272,28 juta rupiah dan 7.546 juta rupiah tetapi belanja daerahnya mengalami penurunan sebesar 10.138 juta rupiah. Dan kabupaten Aceh utara DAU dan DBH nya mengalami penurunan pada tahun 2014-2015 masing-masing 16.295 juta rupiah dan 98.710 juta rupiah tetapi belanja daerahnya mengalami peningkatan sebesar 331.820 juta rupiah. Seharusnya, jika PDRB, PAD, DAU, dan DBH meningkat maka belanja daerah pun meningkat. Demikian sebaliknya (BPSaceh 2018).

Realita yang sering terjadi, daerah lebih memfokuskan pembiayaan operasional utamanya pada dana transferan dan dituangkan dalam anggaran 
daerahnya. Jika pendapatan daerah berasal dari transferan, maka stimulasi atas belanja yang terjadi berbeda dengan stimulasi dari pendapatan daerah, dan ketika belanja daerah lebih berespon kepada transferan dibanding pendapatannya sendiri maka terjadilah flypaper effect, Oates dalam (Rasyid 2018). Berdasarkan latar belakang tersebut, penulis tertarik untuk menganalisis bagaimana pengaruh antara PDRB, PAD, DAU, dan DBH pada belanja daerah Provinsi Aceh 2013-2017.

Pengaruh Pertumbuhan Ekonomi terhadap Belanja Daerah. Sihombing (2011) menyatakan bahwa besar kecilnya dana yang dibutuhkan bergantung pada luas wilayah dan demografi, jumlah dan kebutuhan penduduk serta hal lain yang berpengaruh terhadap pertumbuhan sosial ekonomi dan perkembangan sektor pendapatan daerah, minimal mempercepat pembangunan seperti yang diharapkan. Pendapatan tersebut dapat menjadi sumber pembelanjaan daerah dalam mencapai pertumbuhan ekonomi daerah. Penelitian Wulandari dkk., (2012) menyatakan bahwa pertumbuhan ekonomi mempunyai pengaruh signifikan pada belanja daerah. Semakin tinggi belanja daerah, maka semakin baik pertumbuhan ekonomi. Diharapkan pemerintah daerah dapat mendistribusikan dana belanja daerah untuk menambah aset tetap yang didasari akan kebutuhan infrastruktur dalam pelaksanaan kewajiban pemerintahan maupun fasilitas pubik.

Pengaruh PAD terhadap Belanja Daerah. Menurut Rosidin (2015) setiap tahun kebutuhan pemerintah dan masyarakat di setiap daerah selalu meningkat. Dampaknya, jumlah dana untuk belanja daerah pun selalu meningkat. Namun, tetap saja jumlah belanja tersebut bergantung pada kapasitas pendapatan daerah. (Sihombing 2011) menyatakan semakin tinggi penghasilan seseorang maka 
kesanggupan untuk membayar semakin tinggi pula. Semakin besar nilai pendapatan daerah maka kemandirian dalam mendanai tugas daerah semakin besar, terutama belanja daerahnya. Kemampuan untuk menggali sumber keuangan sendiri lah kunci dasar suatu daerah otonom bangkit dalam pembangunannya. Keuangan daerah dinyatakan berhasil apabila secara berkesinambungan daerah tersebut mampu meningkatkan penerimaannya bersamaan dengan perkembangan perekonomian. Penelitian Mulyadi dkk., (2010) mengatakan bahwa PAD mempunyai pengaruh signifikan pada belanja daerah. PAD yang mengalami peningkatan, juga akan meningkatkan belanja daerah. Oleh karena itu, peningkatan PAD diharapkan secara signifikan berefek pada pengalokasian belanja daerah terutama dalam mengurangi pembiayaan dari pemerintah pusat.

Pengaruh DAU terhadap Belanja Daerah. Menurut Rosidin (2015) meskipun kekayaan keuangan semakin besar, namun tidak ada satu daerah pun yang secara penuh mampu memenuhi belanja rumah tangganya sendiri. Dimana, sebagian besar keuangan daerah berupa subsidi dari pemerintah pusat. Apabila pembiayaan kebutuhan pengeluaran daerah masih kurang, maka kekurangan tersebut dapat dibiayai menggunakan subsidi oleh pemerintah pusat. (Mardiasmo 2009) juga menyatakan bahwa kewenangan yang daerah miliki tidak sekedar penggunaan PAD saja, melainkan juga kewenangan penggunaan Dana Perimbangan berupa DAU dari pemerintah pusat yang dialokasikan untuk menangani keperluan pembelanjaan daerah. Penelitian Salindeho (2016) mengatakan bahwa DAU mempunyai pengaruh signifikan dalam belanja daerah. Jika terjadi peningkatan, hal tersebut akan meningkatkan belanja daerah 
Pengaruh DBH terhadap Belanja Daerah. Mardiasmo (2009) menyatakan bahwa besarnya dana perimbangan akan berimplikasi pada struktur penerimaan APBD yakni jumlah penerimaan akan membesar. Hal ini menunjukkan adanya pergeseran anggaran yang dikelola pemerintahan pusat beralih kepada pemerintahan daerah salah satunya yakni DBH. Penggunaan dana tersebut harus dilakukan secara efektif dan efisien, disertai adanya peningkatan sumber daya manusia. DBH tersebut menjadi salah satu dana yang dapat digunakan dalam membiayai kebutuhan di daerah. Penelitian Yusriadi (2017) mengatakan bahwa DBH merupakan pendapatan yang berpotensial sebagai sumber modal dalam mendanai kebutuhan pembangunan dan belanja daerah. Semakin tinggi DBH maka ekspektasi tingkat pembangunan semakin tinggi. Hasil penelitiannya menyatakan bahwa Daerah yang mendapatkan DBH yang besar, belanja daerahnya pun cenderung besar.

Berdasarkan uraian tersebut, maka disajikan kerangka konseptual sebagaimana Gambar 1

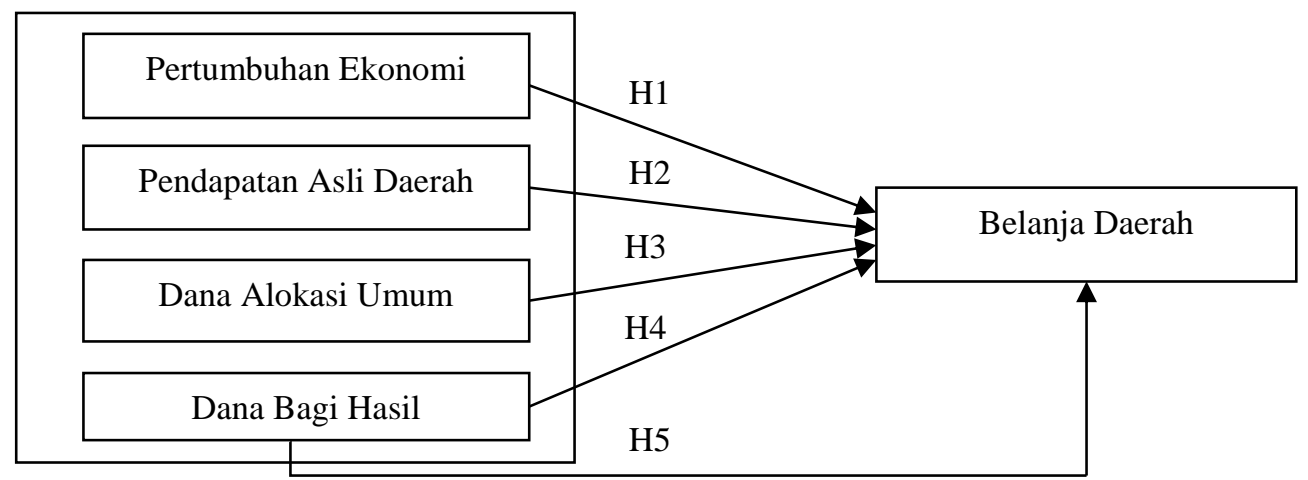

Gambar 1 Kerangka Konseptual 


\section{METODE PENELITIAN}

Metode dalam penelitian ini menggunakan metode kuantitatif dan jenis deskriptif. Penelitian ini dilakukan pada Provinsi Aceh melalui Badan Pusat Statistik Provinsi Aceh. Pengumpulan sumber data yakni dengan studi dokumentasi seperti jurnal pendukung, buku, dan laporan realisasi APBD dan PDRB Provinsi Aceh yang dimuat pada website Badan Pusat Statistik Provinsi Aceh http://aceh.bps.go.id serta menggunakan jenis data sekunder.

Populasi dan sampel berjumlah 23 kabupaten/kota pemerintahan daerah Provinsi Aceh periode 2013-2017, dengan menggunakan teknik sampling jenuh dengan mengambil seluruh populasi sebagai sampel (Sugiyono 2010). Dengan periode penelitian 5 tahun, maka jumlah observasi ialah 115 (23 dikali 5) serta terdiri atas data pertumbuhan ekonomi (PDRB atas harga konstan), PAD, DAU, DBH dan belanja daerah.

Hipotesis penelitian ini diuji menggunakan metode analisis regresi berganda dan merupakan modifikasi penelitian (Tuasikal 2008) dengan mengganti beberapa variabel sesuai variabel pada penelitian ini, sehingga diperoleh persamaan regresi sebagai berikut:

$$
\text { LN_BD }=a+b_{1} \text { LN_PDRB }+b_{2} \text { LN_PAD }+b_{3} \text { LN_DAU }+b_{4} L N \_D B H+e
$$

Keterangan :

$\begin{array}{lll}\text { LN_BD } & = & \text { Belanja daerah } \\ \mathrm{a} & = & \text { Konstanta } \\ \mathrm{b}_{1}, \mathrm{~b}_{2}, \mathrm{~b}_{3}, \mathrm{~b}_{4} & = & \text { koefisien regresi }\end{array}$




$\begin{array}{lll}\text { LN_PDRB } & = & \text { PDRB } \\ \text { LN_PAD } & = & \text { PAD } \\ \text { LN_DAU } & = & \text { DAU } \\ \text { LN_DBH } & = & \text { DBH } \\ \mathrm{e} & = & \text { Standar error }\end{array}$

HASIL DAN PEMBAHASAN

Tabel 1

Statistik Deskriptif

\begin{tabular}{lrrrrr}
\hline & N & Minimum & Maximum & Mean & \multicolumn{1}{c}{$\begin{array}{c}\text { Std. } \\
\text { Deviation }\end{array}$} \\
\hline PDRB & 115 & 841005,66 & 17836613,02 & 4963965,64 & 3835335,32 \\
PAD & 115 & 7877,00 & 377268,00 & 91264,09 & 66960,94 \\
DAU & 115 & 251635,00 & 872481,00 & 521968,11 & 148329,54 \\
DBH & 115 & 12477,00 & 511392,00 & 45927,30 & 78251,21 \\
BD & 115 & 352967,00 & 2714590,00 & 1059837,38 & 461912,49 \\
$\begin{array}{l}\text { Valid N } \\
\text { (listwise) }\end{array}$ & 115 & & & & \\
\hline Sumber : Hasil Pengolahan Data, 2019 & & & & \\
\hline
\end{tabular}

Berdasarkan Tabel 1 tampak data variabel PDRB memiliki nilai antara 841.005,66 sampai 17.836.613,02 dengan mean sebesar 4.963.965,64. PAD antara 7.877,00 sampai 377.268,00 dengan mean sebesar 91.264,09. DAU antara 251.635,00 sampai 872.481,00 dengan mean 521.968,11. DBH antara 124.77,00 sampai 511.392,00 dengan mean 45.927,30 dan belanja daerah antara 352.967,00 sampai 2.714.590,00 dengan mean 1059837,38. Serta standar deviasi variabel PDRB, PAD, DAU, DBH dan belanja daerah berturut-turut yakni 3.835.335,32; 66960,$94 ; 148329,54 ; 78251,21 ; 461912,49$. 
Uji Normalitas. Menurut (Ghozali 2016) uji ini digunakan dalam pengujian ada tidaknya distribusi normal pada variabel penggangu/residual melalui analisis grafik dan statistik. Berikut ini gambar dan tabel hasil analisis uji normalitas.

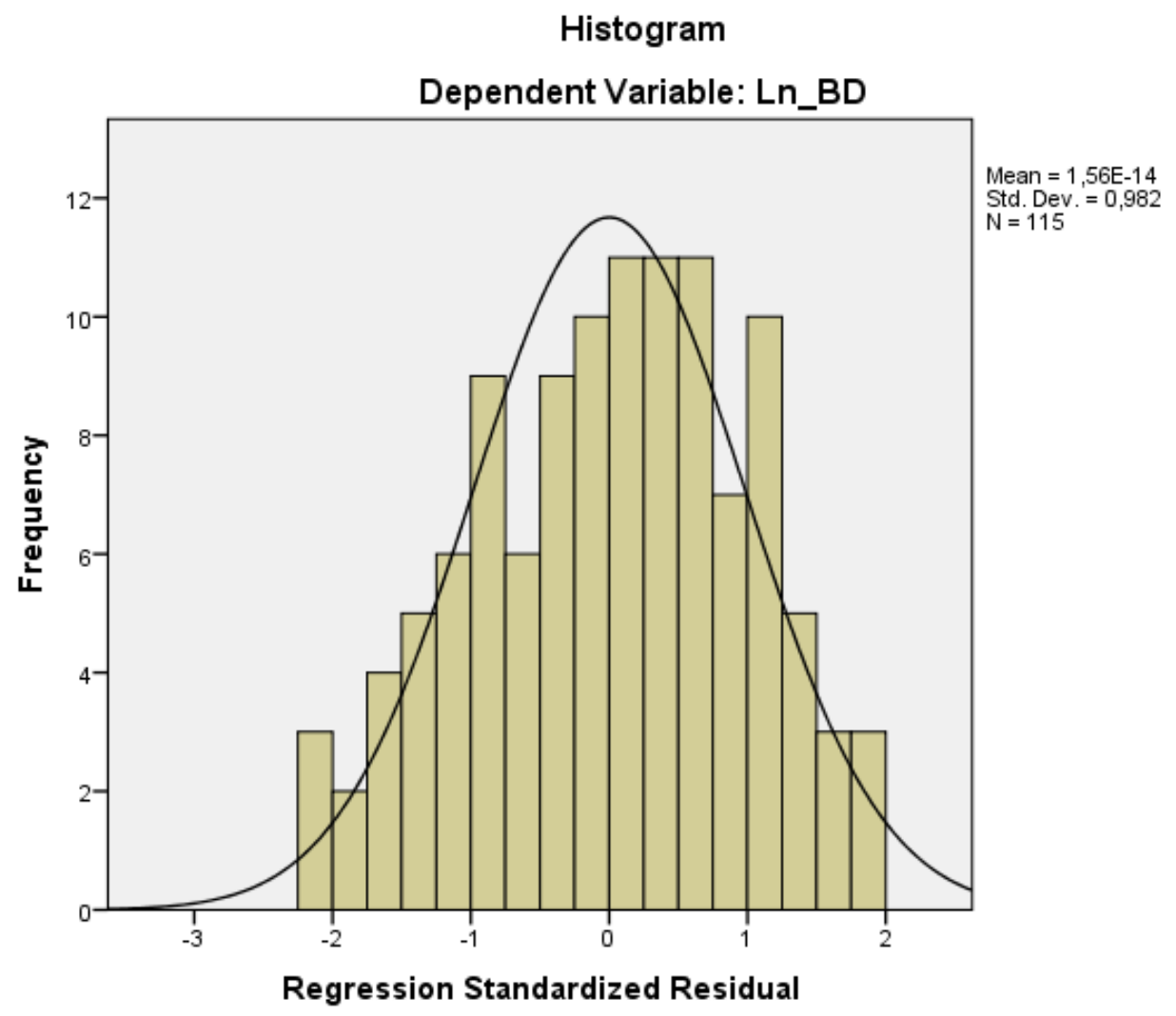

Sumber : Hasil Pengolahan Data, 2019

\section{Gambar 2. \\ Uji Normalitas Histogram}

Hasil uji Gambar 2 menunjukan bahwa grafik tersebut cenderung simetri sehingga dapat dikatakan memenuhi ketentuan normalitas. Hasil uji Gambar 3 menunjukkan titik-titik tersebar mendekati diagonal, sehingga dinyatakan normal. 


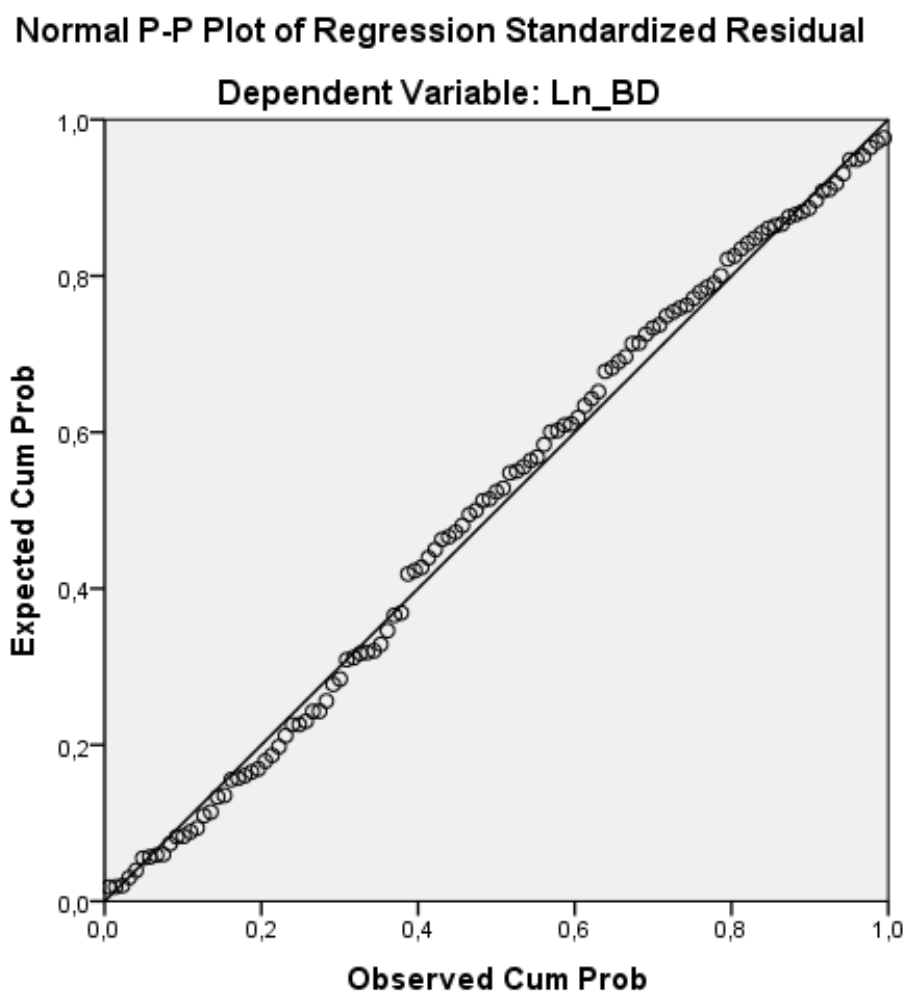

Sumber : Hasil Pengolahan Data, 2019

Gambar 3.

Uji Normalitas P-P Plot

Tabel 2

Uji Normalitas Kolmogorov Smirnov

\begin{tabular}{llr}
\hline \multicolumn{2}{c}{ One-Sample Kolmogorov-Smirnov Test } \\
\hline & & \multicolumn{1}{c}{ Unstandardized } \\
Residual \\
$\mathrm{N}$ & Mean & 115 \\
Normal Parameters ${ }^{\mathrm{a}, \mathrm{b}}$ & Std. Deviation & $0 \mathrm{E}-7$ \\
& Absolute &, 15179026 \\
& Positive &, 047 \\
Most Extreme Differences & Negative &, 039 \\
& &,- 047 \\
Kolmogorov-Smirnov Z & &, 507 \\
Asymp. Sig. (2-tailed) & &, 959 \\
\hline
\end{tabular}

Sumber : Hasil Pengolahan Data, 2019 
Tabel 2 tampak nilai signifikan $0,959>0,05$, dengan demikian data sudah berdistribusi normal.

Uji Multikolonieritas. Menurut Ghozali (2016), uji ini digunakan untuk mengetahui apakah diantara variabel bebas mempunyai korelasi dimana semestinya tidak terdapat korelasi. Untuk mencegah hal tersebut maka nilai tolerance $>0.10$ dan $\mathrm{VIF}<10$.

Tabel 3.

Uji Multikoloniearitas

\begin{tabular}{|c|c|c|c|}
\hline \multirow{2}{*}{\multicolumn{2}{|c|}{ Model }} & \multicolumn{2}{|c|}{ Collinearity Statistics } \\
\hline & & \multirow[t]{2}{*}{ Tolerance } & \multirow[t]{2}{*}{ VIF } \\
\hline \multirow{5}{*}{1} & (Constant) & & \\
\hline & Ln_PDRB &, 181 & 5,530 \\
\hline & Ln_PAD & ,291 & 3,434 \\
\hline & Ln_DAU & ,209 & 4,789 \\
\hline & Ln_DBH &, 563 & 1,775 \\
\hline
\end{tabular}

Sumber : Hasil Pengolahan Data, 2019

Berdasarkan Tabel 3, diperoleh besarnya nilai tolerance variabel LN_PDRB, LN_PAD, LN_DAU, dan LN_DBH melebihi 0,10, serta nilai VIF berada di bawah 10. Sehingga tidak ada multikolonieritas.

Uji Autokorelasi. Menurut Sunyoto (2016), uji ini digunakan untuk mengetahui ada tidaknya penggangu antara tahun sekarang dengan tahun lalu. Uji ini dilakukan memakai $D W$ test, dengan syarat yakni $-2<\mathrm{DW}<+2$. Pada Tabel 4 oleh karena DW $=-2<0,972<2$, dengan demikian hasilnya tidak terjadi autokorelasi. 
Tabel 4.

Uji Autokorelasi

\begin{tabular}{lr}
\hline Model & \multicolumn{1}{l}{$\begin{array}{l}\text { Durbin- } \\
\text { Watson }\end{array}$} \\
\hline 1 &, 972 \\
\hline
\end{tabular}

Sumber : Hasil Pengolahan Data, 2019

Uji Heterokedastisitas. Menurut (Ghozali 2016), uji ini dilakukan untuk mengukur persamaan dan perbedaan varian nilai residual di model regresi. Metode untuk melihat heterokedastisitas, yaitu metode chart (Diagram Scatterplot) dan menggunakan Uji Park. Pada Gambar 3 menunjukkan bahwa titik-titik tersebar tidak teratur, sehingga dinyatakan tidak adanya heterokedastisitas.

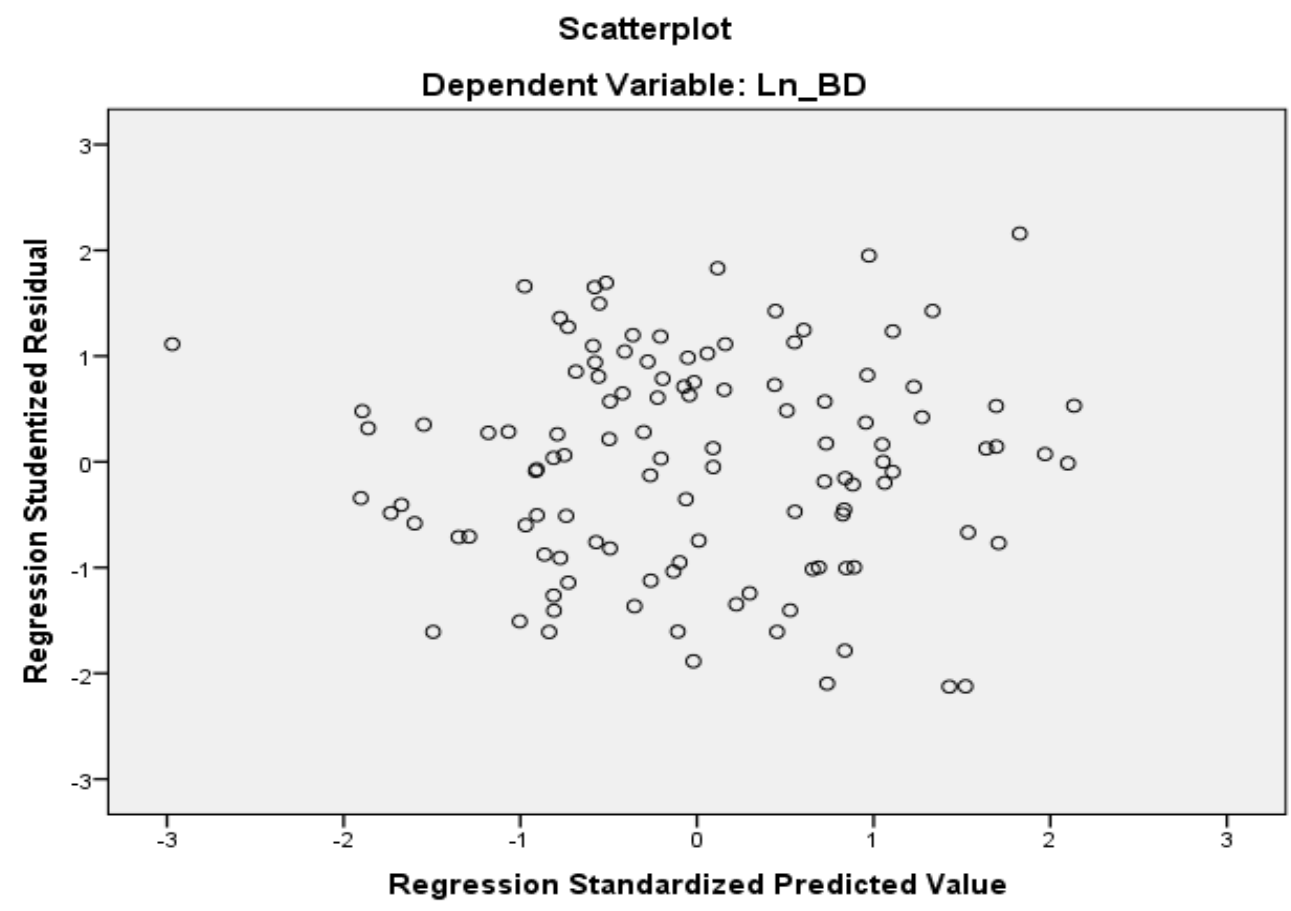

Sumber : Hasil Pengolahan Data, 2019

Gambar 4.

Uji Heterokedastisitas 
Tabel 5.

Uji Park

\begin{tabular}{|c|c|c|c|c|c|c|}
\hline \multicolumn{7}{|c|}{ Coefficients $^{\mathrm{a}}$} \\
\hline \multirow{2}{*}{\multicolumn{2}{|c|}{ Model }} & \multicolumn{2}{|c|}{$\begin{array}{l}\text { Unstandardized } \\
\text { Coefficients }\end{array}$} & \multirow{2}{*}{$\begin{array}{c}\text { Standardized } \\
\text { Coefficients }\end{array}$} & \multirow[t]{2}{*}{$\mathbf{t}$} & \multirow[t]{2}{*}{ Sig. } \\
\hline & & B & Std. Error & & & \\
\hline \multirow{5}{*}{1} & (Constant) & 3,193 & 15,966 & & ,200 &, 842 \\
\hline & Ln_PDRB &, 170 & ,696 &, 054 &, 244 & ,808 \\
\hline & Ln_PAD &,- 382 &, 582 &,- 114 &,- 656 &, 513 \\
\hline & Ln_DAU &,- 776 & 1,797 &,- 089 &,- 432 & ,667 \\
\hline & Ln_DBH & ,361 &, 425 & ,106 &, 849 & ,398 \\
\hline
\end{tabular}

Sumber : Hasil Pengolahan Data, 2019

Dikarenakan terdapat heterokedastisitas dalam model regresi, maka dilakukan transformasi menggunakan uji park. Hasil uji park pada Tabel 5 tampak nilai signifikan seluruh variabel berada di atas 0,05 sehingga dinyatakan tidak adanya heteroskedastisitas.

Tabel 6.

Persamaan Regresi

\begin{tabular}{|c|c|c|c|c|c|c|}
\hline \multicolumn{7}{|c|}{ Coefficients $^{\mathbf{a}}$} \\
\hline & \multicolumn{2}{|c|}{$\begin{array}{l}\text { Unstandardized } \\
\text { Coefficients }\end{array}$} & \multirow{2}{*}{$\begin{array}{c}\begin{array}{c}\text { Standardize } \\
\text { d } \\
\text { Coefficients }\end{array} \\
\text { Beta }\end{array}$} & \multirow[t]{2}{*}{$\mathbf{t}$} & \multirow[t]{2}{*}{ Sig. } \\
\hline & & B & Std. Error & & & \\
\hline \multirow{5}{*}{1} & Model & $-1,772$ & 1,002 & & $-1,769$ & ,080 \\
\hline & Ln_PDRB &,- 165 & ,044 &,- 303 & $-3,771$ & 000 \\
\hline & Ln_PAD &, 274 & ,037 & ,476 & 7,508 & ,000 \\
\hline & Ln_DAU & 1,130 & ,113 & ,749 & 10,019 & 000 \\
\hline & Ln_DBH &, 015 & ,027 &, 026 &, 566 & ,572 \\
\hline
\end{tabular}

Sumber : Hasil Pengolahan Data, 2019

LN_BD $=-1,772-0,165$ LN_PDRB + 0,274 LN_PAD + 1,130 LN_DAU + 0,015

LN_DBH 
Hasil analisis data penelitian menggunakan SPSS, maka hasil analisis dapat dilihat pada Tabel 6. Makna dari persamaan regresi linear berganda tersebut yakni nilai konstanta $=-1,772$, berarti bahwa nilai variabel bebas yaitu PDRB, PAD, DAU, dan DBH bernilai konstan, maka nilai BD turun sebesar 1,772. Koefisien PDRB -0,165, berarti setiap kenaikan satu satuan PDRB, maka nilai BD turun 0,165 satuan. Koefisien PAD 0,274, berarti setiap kenaikan satu satuan PAD, maka nilai BD naik 0,274 satuan. Koefisien DAU 1,130, berarti setiap kenaikan satu satuan DAU, maka nilai BD naik 1,130 satuan. Koefisien DBH 0,015, berarti setiap kenaikan satu satuan DBH, maka nilai BD naik 0,015 satuan, dengan asumsi variabel lain dianggap nol.

Koefisien Determinasi Hipotesis. Menurut Ghozali (2016), $\mathrm{R}^{2}$ digunakan untuk menerangkan kekuatan suatu model menjelaskan variabel bebas. Pada Tabel 7 tampak Adjusted R Square $=0,867$. Artinya 86,7\% dari variabel belanja daerah dapat dijelaskan oleh variabel pertumbuhan ekonomi, PAD, DAU, dan DBH dan 0,133 atau 13,3\% dijabarkan oleh variabel lain, contoh Dana Alokasi Khusus, SiLPA, dan Investasi.

Tabel 7.

Uji Koefisien Determinasi

\begin{tabular}{|c|c|c|c|c|c|c|}
\hline \multicolumn{7}{|c|}{ Model Summaryb } \\
\hline \multirow{2}{*}{$\begin{array}{l}\text { Mo } \\
\text { del }\end{array}$} & \multirow[t]{2}{*}{$\mathbf{R}$} & \multirow{2}{*}{$\begin{array}{c}\text { R } \\
\text { Square }\end{array}$} & \multirow{2}{*}{$\begin{array}{l}\text { Adjusted R } \\
\text { Square }\end{array}$} & \multirow{2}{*}{$\begin{array}{l}\text { Std. Error of } \\
\text { the Estimate }\end{array}$} & \multicolumn{2}{|c|}{ Change Statistics } \\
\hline & & & & & $\begin{array}{l}\text { R Square } \\
\text { Change }\end{array}$ & $\begin{array}{c}\mathbf{F} \\
\text { Change }\end{array}$ \\
\hline 1 &, $934^{\mathrm{a}}$ & ,871 & 867 &, 15453 &, 871 & 186,470 \\
\hline
\end{tabular}

Uji F. Menurut Ghozali (2016), menunjukan adakah secara keseluruhan semua variabel berpengaruh pada variabel terikat. Tabel 8 menunjukkan nilai $F_{\text {hitung }}$ 
$=186,470$ dan nilai sig $=0,000$. Sedangkan nilai $F_{\text {tabel }}$ pada $\alpha=0,05$ adalah $2,45\left(\mathrm{df}_{1}\right.$ $=4$, dan $\left.\mathrm{df}_{2}=110\right)$. Karena nilai $F_{\text {hitung }}>F_{\text {tabel }}(186,470>2,45)$ dan nilai signifikan $0,000<0,05$ dinyatakan secara bersama-sama PDRB, PAD, DAU dan DBH berpengaruh signifikan terhadap belanja daerah pada Provinsi Aceh Periode 20132017.

Tabel 8.

Uji Hipotesis Secara Simultan (Uji F)

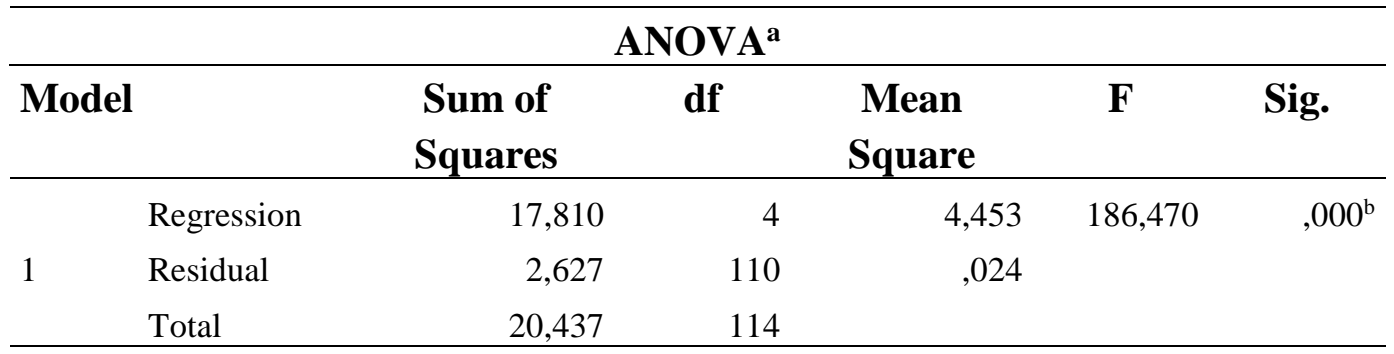

Sumber : Hasil Pengolahan Data , 2019

Uji t. Menurut Ghozali (2016) menunjukan adakah setiap variabel penjelas mempunyai hubungan pada variabel terikat. Tabel 9 menunjukkan hasil uji parsial dengan $t_{\text {tabel }}$ untuk $\alpha=0,05$ pada $\mathrm{df}=111$ ialah 1,98157

Tabel 9.

Uji Hipotesis Secara Simultan (Uji t)

\begin{tabular}{|c|c|c|c|c|c|c|}
\hline \multirow{3}{*}{\multicolumn{2}{|c|}{ Model }} & \multicolumn{3}{|c|}{ Coefficients $^{a}$} & \multirow{3}{*}{$\mathbf{t}$} & \multirow{3}{*}{ Sig. } \\
\hline & & \multicolumn{2}{|c|}{$\begin{array}{l}\text { Unstandardized } \\
\text { Coefficients }\end{array}$} & \multirow{2}{*}{$\begin{array}{c}\begin{array}{c}\text { Standardize } \\
\text { d } \\
\text { Coefficients }\end{array} \\
\text { Beta }\end{array}$} & & \\
\hline & & B & Std. Error & & & \\
\hline \multirow{5}{*}{1} & (Constant) & $-1,772$ & 1,002 & & $-1,769$ & ,080 \\
\hline & Ln_PDRB &,- 165 &, 044 &,- 303 & $-3,771$ & ,000 \\
\hline & Ln_PAD &, 274 & 037 &, 476 & 7,508 & 000 \\
\hline & Ln_DAU & 1,130 &, 113 &, 749 & 10,019 & 000 \\
\hline & Ln_DBH &, 015 & ,027 & 026 & ,566 &, 572 \\
\hline
\end{tabular}

Sumber : Hasil Pengolahan Data , 2019

Hasil pengujian uji t variabel LN_PDRB thitung sebesar $-3,771$ dengan $\alpha=0,000$ yang memenuhi kriteria nilai signifikan $\alpha<0,05$. Nilai $-\mathrm{t}_{\text {hitung }}<-\mathrm{t}_{\text {tabel }}(-3,771<-$ 
1,981), artinya PDRB memiliki pengaruh negatif dan signifikan terhadap belanja daerah pada Provinsi Aceh Periode 2013-2017. Hal ini tampak melalui PDRB Kabupaten/Kota Provinsi Aceh yang semakin meningkat dari tahun ke tahun. Akan tetapi, jika dilihat pada belanja daerahnya, sebagian daerah mengalami penurunan belanja daerah pada tahun 2016-2017 dengan tetap meningkatkan pertumbuhan ekonominya. Berarti dapat dikatakan bahwa pertumbuhan ekonomi yang baik didukung oleh belanja daerah yang baik pula yakni dengan tetap meminimalisir belanja daerah secara efektif dan efisien.

Hasil ini juga sependapat dengan penelitian Wulandari dkk., (2012) yakni pertumbuhan ekonomi mempunyai pengaruh signifikan dalam belanja daerah. Dimana fungsi pemerintah ialah sebagai fungsi pembangunan yang ditujukan pada peningkatan pertumbuhan ekonomi. Dalam kebijakan pembangunan tersebut, perlu adanya kebijakan penganggaran alokasi dana sesuai dengan kebutuhan pembangunan. Penelitian tersebut menggunakan data penelitian 8 tahun sedangkan penelitian ini hanya 5 tahun periode penelitian.

Hasil pengujian uji t variabel LN_PAD thitung sebesar 7,508 dengan $\alpha=0,000$ yang memenuhi kriteria nilai signifikan $\alpha<0,05$. Nilai $t_{\text {hitung }}>t_{\text {tabel }}(7,508>1,981)$, artinya PAD memiliki pengaruh positif dan signifikan terhadap belanja daerah pada Provinsi Aceh Periode 2013-2017. Hal ini tampak melalui data PAD yang cenderung meningkat dan disertai dengan peningkatan belanja daerah. Dan ketika PAD menurun, belanja daerahnya pun ikut menurun seperti pada Kabupaten Aceh Selatan dan Kota Banda Aceh tahun 2016-2017. 
Hasil ini juga sependapat dengan penelitian Mulyadi dkk., (2010) yakni PAD mempunyai pengaruh signifikan terhadap belanja daerah. Dimana dalam pembiayaan kebutuhan daerahnya pemerintah daerah diharapkan sanggup membangkitkan sumber dana melalui PAD. Dibanding dengan penelitian tersebut penelitian ini memiliki kelemahan karena masih belum mencakup penelitian tentang respon belanja yang ditimbulkan (flypaper effect).

Hasil pengujian uji $\mathrm{t}$ variabel LN_DAU thitung sebesar 10,019 dengan $\alpha=0,000$ yang memenuhi kriteria nilai signifikan $\alpha<0,05$. Nilai $t_{h i t u n g}>t_{\text {tabel }}$ $(10,019>1,981)$, artinya DAU memiliki pengaruh positif dan signifikan terhadap belanja daerah pada Provinsi Aceh Periode 2013-2017. Hal ini tampak melalui data DAU yang cenderung naik dan diikuti kenaikan belanja daerah. Dan meski belanja daerah mengalami penurunan namun DAU nya bernilai konstan seperti pada Kabupaten Aceh Selatan tahun 2016-2017. Berarti DAU yang tidak mengalami kenaikan pun turut mengakibatkan penurunan belanja daerah.

Hasil ini juga sependapat dengan penelitian Salindeho (2016) yakni DAU mempunyai pengaruh signifikan dalam belanja daerah. Jika terjadi peningkatan, hal tersebut akan meningkatkan belanja daerah. Hal ini menandakan bahwa DAU cukup berpotensi membantu daerah dalam menutupi kekurangan sumber pendapatan untuk belanja daerahnya. Namun, sangat disayangkan apabila DAU tersebut dijadikan dana utama untuk belanja daerah karena hal tersebut dapat menjadikan potensi pendanaan daerah sendiri mengalami kemerosotan. 
Hasil pengujian uji t variabel LN_DBH $t_{\text {hitung }}$ sebesar 0,566 dengan $\alpha=0,572$ dan tidak memenuhi kriteria nilai signifikan. Nilai $t_{\text {hitung }}<t_{\text {tabel }}(0,566<1,981)$, artinya secara parsial DBH tidak memiliki pengaruh terhadap belanja daerah pada Provinsi Aceh Periode 2013-2017. Hasil ini selaras dengan penelitian Rasyid (2018) yang menyatakan bahwa DBH tidak berpengaruh secara signifikan terhadap belanja daerah. Akan tetapi, hasil ini tidak selaras dengan penelitian Yusriadi (2017) yakni DBH berpengaruh secara signifikan terhadap belanja daerah. Tampak bahwa nilai DBH pada penelitian ini lebih cenderung mengalami penurunan seperti pada Kabupaten Aceh Tenggara namun belanja daerah nya mengalami kenaikan.

\section{SIMPULAN DAN SARAN}

Berdasarkan hasil penelitian yang telah dilakukan, maka dapat diambil kesimpulan bahwa secara parsial PDRB , PAD dan DAU memiliki pengaruh dan signifikan terhadap belanja daerah di Provinsi Aceh yang berarti bahwa PDRB, PAD dan DAU dapat memenuhi serta meningkatkan belanja daerah pada kabupaten/kota di Provinsi Aceh, sedangkan DBH tidak memiliki pengaruh dan tidak signifikan terhadap belanja daerah di Provinsi Aceh yang berarti bahwa DBH belum dapat memenuhi keperluan belanja daerah pada kabupaten/kota di Provinsi Aceh. Dan secara simultan PDRB, PAD, DAU, dan DBH memiliki pengaruh dan signifikan terhadap belanja daerah di Provinsi Aceh yang berarti bahwa secara bersama-sama PDRB, PAD, DAU, dan DBH dapat memenuhi keperluan belanja daerah pada kabupaten/kota di Provinsi Aceh. 
Penelitian ini memiliki kelemahan karena hanya menggunakan Provinsi Aceh sebagai sampel sehingga tidak mencakup data yang luas. Saran dalam penelitian ini ialah agar pemerintah daerah terus mengatur penggunaan belanja daerah secara efektif dan efisien berdasarkan kebutuhan dan kemampuan keuangan daerah. Peningkatan PAD pun penting untuk diperhatikan terutama di beberapa kota/kabupaten yang masih sangat rendah PAD nya, dan ketergantungan pada dana transferan pemerintah pusat pun dapat dikurangi. Bagi peneliti berikutnya, dianjurkan untuk melakukan penelitian terhadap objek lain (mis. Provinsi Jawa Timur atau Jawa Tengah), penambahan variabel seperti variabel moderating, penggunaan uji-uji yang lain, serta pemakaian data yang lebih komplit dengan ruang lingkup waktu penelitian yang lebih panjang.

\section{REFERENSI}

BPSaceh. 2018. "Statistik Keuangan Pemerintah Daerah Provinsi Aceh 20132017." Badan Pusat Statistik Provinsi Aceh, 142.

Ghozali, Imam. 2016. Aplikasi Analisis Multivariate Dengan Program SPSS. Semarang: Badan Penerbitan Universitas Dipenogoro.

Mardiasmo. 2009. Otonomi Dan Manajemen Keuangan Daerah. Yogyakarta: Andi.

Mulyadi, Huteman, Lizar Alfansi, and Benardin. 2010. "Analisis Pengaruh Dana Alokasi Umum (DAU) Dan Pendapatan Asli Derah (PAD) Terhadap Belanja Daerah Terhadap Belanja Daerah Kabupaten/Kota Di Bengkulu.” Jurnal Ekonomi Dan Perencanaan Pembangunan 3(1):51-58.

Rasyid, Moh. 2018. "Pengaruh Dana Alokasi Umum, Dana Alokasi Khusus, Dana Bagi Hasil Dan Pendapatan Asli Daerah Terhadap Belanja Daerah Kabupaten / Kota Provinsi Sulawesi Tengah.” 205 e Jurnal Katalogis 6(1):204-16.

Rosidin. 2015. Otonomi Daerah Dan Desentralisasi. Bandung: Pustaka Setia.

Salindeho, Claudia. 2016. "Pengaruh Dana Alokasi Umum (DAU) Dan Dana 
Alokasi Khusus (DAK) Terhadap Belanja Daerah Di Provinsi Sulawesi Utara." Jurnal EMBA 4(3):705-16.

Sihombing, Yonge L. v. 2011. Manajemen APBD (Anggaran Pendapatan Dan Belanja Daerah). Medan: Bina Media Perintis.

Sugiyono. 2010. Metodologi Penelitian Kuantitatif, Kualitatif, Dan $R \& D$. Bandung: Alfabeta.

Sukirno, Sadono. 2016. Makroekonomi Teori Pengantar. Ke-3. Jakarta: Raja Grafindo Persada.

Sunyoto, Danang. 2016. Metodologi Penelitian Akuntansi. Bandung: Refika Aditama.

Tuasikal, Askam. 2008. "Pengaruh DAU, DAK, PAD, Dan PDRB Terhadap Belanja Modal Pemerintah Daerah Kabupaten/Kota Di Indonesia." Jurnal Telaah \& Riset Akuntansi 1(2):142-54.

Wulandari, Fitria, Asrizal, and Jolianis. 2012. "Pengaruh Pertumbuhan Ekonomi (PDRB), Pendapatan Asli Daerah (PAD) Dan Dana Alokasi Umum Terhadap Belanja Daerah Di Kabupaten Pasaman Barat.” STKIP PGRI Sumatera Barat (1).

Yusriadi, Sri Mulyati. 2017. "Dana Bagi Hasil Dan Dana Alokasi Umum Terhadap Belanja Daerah Pada Provinci Aceh.” AGREGAT:Jurnal Ekonomi Dan Bisnis 1(2):211-20. 